Received $\quad 16.05 .2016$ Reviewed 26.06.2016 Accepted 08.07.2016

A - study design

B - data collection

C - statistical analysis

D - data interpretation

E - manuscript preparation

F - literature search

\section{An experimental study of the surface and subsurface irrigation methods with respect to soil moisture on grape yard}

\author{
Sharad J. KADBHANE ${ }^{1)}$ ABCDEF, Vivek L. MANEKAR ${ }^{2) ~ A D}$
}

Sardar Vallabhbhai National Institute of Technology, Surat, Gujarat, India; e-mail: sharad_kadbhane@rediffmail.com, vivek_manekar@yahoo.co.in

For citation: Kadbhane S.J., Manekar V.L. 2016. An experimental study of the surface and subsurface irrigation methods with respect to soil moisture on grape yard. Journal of Water and Land Development. No. 31 p. 73-85. DOI: 10.1515/jwld-2016-0038.

\begin{abstract}
In this study, field experiment has been carried out on the grape yard during the summer, Rainy, and winter seasons using different irrigation methods and measuring its impact on moisture retention. Six different irrigation methods such as drip irrigation (DI), drip irrigation with plastic mulching (DIPM), drip irrigation with organic mulching (DIOM), subsurface irrigation with stone column (SISC), subsurface irrigation with mud pot (SIMP), and subsurface irrigation with plastic bottles (SIPB) are used during experimental work. CROPWAT-8.0 model (FAO) is used to find out crop water requirements. Soil moisture is measured using soil moisture sensors fixed in the depth of 30 and $60 \mathrm{~cm}$ at the same location. Climatic parameters are obtained from the automatic weather station which is located near the experimental field. Multifactorial statistical analysis has been carried out using recorded soil moisture and climatic data. As per experimental results and analysis, it is observed that drip irrigation with the plastic mulching method is found to be the best method of irrigation for soil moisture retention among all other methods due to its highest soil moisture retention value as $25-30 \%$. Whereas subsurface irrigation with the plastic bottle method is found to be suitable as it retained $15-20 \%$ soil moisture and material used in this irrigation method is waste material and the cheapest one.
\end{abstract}

Key words: drip irrigation, mud pot, organic mulching, plastic mulching, soil moisture retention, subsurface irrigation, surface irrigation

\section{INTRODUCTION}

Due to climate change, drought disasters are continuously occurring in the Indian subcontinent. A West Agro Climatic Zone of India having semiarid climatic conditions and it is suffering from the insufficient and uneven rainfall in last few years. Adverse effects of uneven rainfall are that in one part of the country suffers due to water scarcity, whereas other part suffering due to high flood conditions. According to most of Global Circulation Models (GCM), temperature has been increased and precipitation has been decreased globally (Intergovernmental Panel of Climate Change) [IPCC 2007]. Since 1972 drought events are frequently occurring in the different agro-climatic zones of India [SIKKA 2009]. These situations are shows impact on the food security of the growing population. The Indian government has already passed the food security bill in 2012, but it is difficult to provide sufficient food to the growing population due to such scarcity and drought events. Grape is contributed the significant role of complete food. The grape crop is also plays the important role in socioeconomic development of the farmers because of its export potential. In the year 2012, India exported $25,85,000$ ton grapes [SAXENA 2015]. But recently due to climatic changes and variations in rainfall it is difficult not only to maintain production of grape but 
also to save the grape yards from ruin. To cultivate one hectare of grape yard 0.7 millions of Indian rupees required [SAXENA 2015]. Such huge amount is made available only after bank loans. Once grape yard is destroying then it is difficult to repay. It is a challenge to produce grape with water scarcity occurring by climatic changes. So it is urging to study, how to maintain soil moisture level using efficient irrigation systems under such scarce conditions. Some of the researchers have been studied on different surface and subsurface irrigation methods. In case of subsurface irrigation methods if emitters are directly inserted in the subsurface there are chances to clogging, once emitters are clogged, it is difficult to unclog in subsurface [LAzArovitch et al. 2006]. So it is necessary to find out the subsurface irrigation methods without a problem of clogging. The grape yield is possible with the reasonable and planned deficit irrigation using drip [FACI et al. 2014]. ARAGÜÉS et al. [2014] has studied in combination with deficit irrigation strategies, its implementation in low-precipitation semiarid areas must be cautiously assessed and monitored. The use of subsurface drip irrigation (SDI) systems may afford an enhancement in irrigation water use productivity. These systems are applying irrigation water straight to the ground [AYARS et al. 1999]. Subsurface drip irrigation method (SDI system) using the perforated PVC pipe is the best method to overcome the clogging problems [MARTÍNEZ, RECA 2014].

In this study, field experiment is carried out on the grape yard using six different irrigation methods. The drip irrigation method which is the most accepted and effective method of irrigation is basically considered in this study for developing different irrigation methods. Developed and used irrigation methods in this experimental study are drip irrigation (DI), drip irrigation with the plastic mulching (DIPM), drip irrigation with organic mulching (DIOM), subsurface irrigation with the stone column (SISC), subsurface irrigation with the mud pot (SIMP) and subsurface irrigation with plastic bottles (SIPB). Laterals and emitters are common in all those mentioned irrigation systems. In case of the surface irrigation methods water is released into the atmosphere from the emitters. In the subsurface irrigation methods, water directly reaches the root zone of the crop. Objective of this study is to find out the efficient soil moisture retention and economically affordable irrigation system among six mentioned systems.

\section{MATERIALS AND METHODS}

\section{STUDY AREA}

This study has been carried out by the performing experimentation work during the period during summer $\left(01^{\text {st }}\right.$ April to $30^{\text {th }}$ June $)$, rainy $\left(01^{\text {st }}\right.$ July to $30^{\text {th }}$ October $)$ and winter $\left(01^{\text {st }}\right.$ November to $30^{\text {th }}$ March) seasons on the table grape (Vitis vinifera cultivars) yard, located at the Nashik district in the West
Agro-Climatic Zone of India (WACZI) at 2004'19” N, $73^{\circ} 54^{\prime} 05^{\prime}$ ' E, and altitude $585 \mathrm{~m}$ a.m.s.l. The study area is flat terrain, semiarid climatic condition, mean annual rainfall of $550 \mathrm{~mm}$ and maximum dry period in the months of April to June. A mean monthly temperature ranges minimum $13.4^{\circ} \mathrm{C}$ in January to maximum $36.4^{\circ} \mathrm{C}$ in May, that means winter is mild and there is no risk of frost, as the absolute minimum temperature is greater than $4^{\circ} \mathrm{C}$. A mean wind speed has recorded high in the month of June as $7 \mathrm{~m} \cdot \mathrm{s}^{-1}$ and low in the month of January as $1.0 \mathrm{~m} \cdot \mathrm{s}^{-1}$. Monthly mean of relative humidity is recorded as $54.45 \%$ with the minimum in warmer months. The climatic conditions of the area are described on the basis of aridity indices by which area is semiarid [ROSSI, CANCELLIERE 2002]. Climatological monthly average data is collected from the Indian Metrological Department (IMD) and Nashik Metrological station for the period of 1981-2013.

\section{EXPERIMENTAL DESIGN}

Initially, six different irrigation systems are designed, fabricated and installed in the field. The schematic view of six irrigation systems such as DI, DIPM, DIOM, SISC, SIMP, and SIPB. In the grape yard under study, plant rows are place in the NorthSouth direction by planting 25 plants in one row with the plant interval of one meter. The distance between two rows is kept $2.1 \mathrm{~m}$, for the convenience of the labors and machinery. Experimental data is generated for six different irrigation methods, and moisture level in $30 \mathrm{~cm}$, and the $60 \mathrm{~cm}$ depth, at the same location.

\section{A DESCRIPTION OF IRRIGATION SYSTEMS}

Drip irrigation (DI) has regular $16 \mathrm{~mm}$ lateral attached to the sub main pipeline of size $65 \mathrm{~mm}$. Each grape plant has two emitters of a capacity $8 \mathrm{dm}^{3} \cdot \mathrm{h}^{-1}$ as shown in the Figure 1a. Water emission varies with pressure so calibration has done with 50 to $400 \mathrm{kP}$ water pressure meter. Water pressure is measured at the time of every irrigation schedule and the water amount given to trees accordingly. This system is common for all six irrigation methods. A wet bulb is started from the earth surface as shown in Figure 1.

Drip irrigation with plastic paper mulching (DIPM) is the system of irrigation in which laterals and emitters covered with one meter wide, a hundred micron thick silver color plastic paper as shown in Figure $1 b$. The estimated life of mulching paper is one year. The edges of paper are covered with surface soil so that paper position could not disturb due to the wind, human, and animal activities. Plastic paper is cut at plant location so that it can cover one meter width of the row exactly. Plastic mulching is resisted direct contact sunlight and the wind with the earth surface and hence reducing evapotranspiration losses whereas wet bulb is started from the earth surface as shown in Figure $1 \mathrm{~b}$ and Photo 1a. 
Drip irrigation with organic mulching (DIOM), is the system of irrigation in which laterals and emitters are covered with one meter wide organic matters like dry grass, bagasse, and grape plant biomass create after pruning. These organic matters are distributed over the surface of the grape plant row $7-10 \mathrm{~cm}$ thick layer as shown in Figure 1c and Photo $1 \mathrm{~b}$. Organic mulching is prevented direct contact sunlight and wind to the earth surface. It is useful to reduce the losses of soil moisture due to evaporation. The wet bulb is starting from the earth surface.

Subsurface irrigation with the stone column (SISC) is another irrigation method wherein $10 \mathrm{~cm}$ diameter and $30 \mathrm{~cm}$ deep underground pit is excavated using the auger and fill it with $2.5-3.0 \mathrm{~cm}$ size stone pieces up to the earth surface. Emitters are inserted on top of the stone column so that water reaches directly to the root zone and inspection of clogging of emitters done easily. Separate columns are constructed both sides of grape plant. Each stone column forms its own wet bulb which is shown in Figure 1d and Photo 1c. The weather-

proof compact basalt stone is used to make the stone column. There is less possibility of clogging of the stone column due to larger size voids are formed between pieces of stone. Water is directly reached to the root zone resulted in reducing evapotranspiration rate. The wet bulb is started from the surface of earth up to the depth of the stone column, i.e. $30 \mathrm{~cm}$, below the earth surface.

Subsurface irrigation with the mud pot (SIMP) irrigation system is consisted of $15 \mathrm{~cm}$ diameter perforated mud-pot, which is locally manufactured and cheapest inserted $10 \mathrm{~cm}$ below the earth surface such that water reaches directly to the root zone of plant and resulted in the reduction of evaporation rate. This system is easy to install, but here chances to break the pot by human activities. So life of this system is uncertain. Emitters are inserted on the top of the mud pot so that water reaches directly at the root zone and inspection of clogging of emitters easily, as shown in
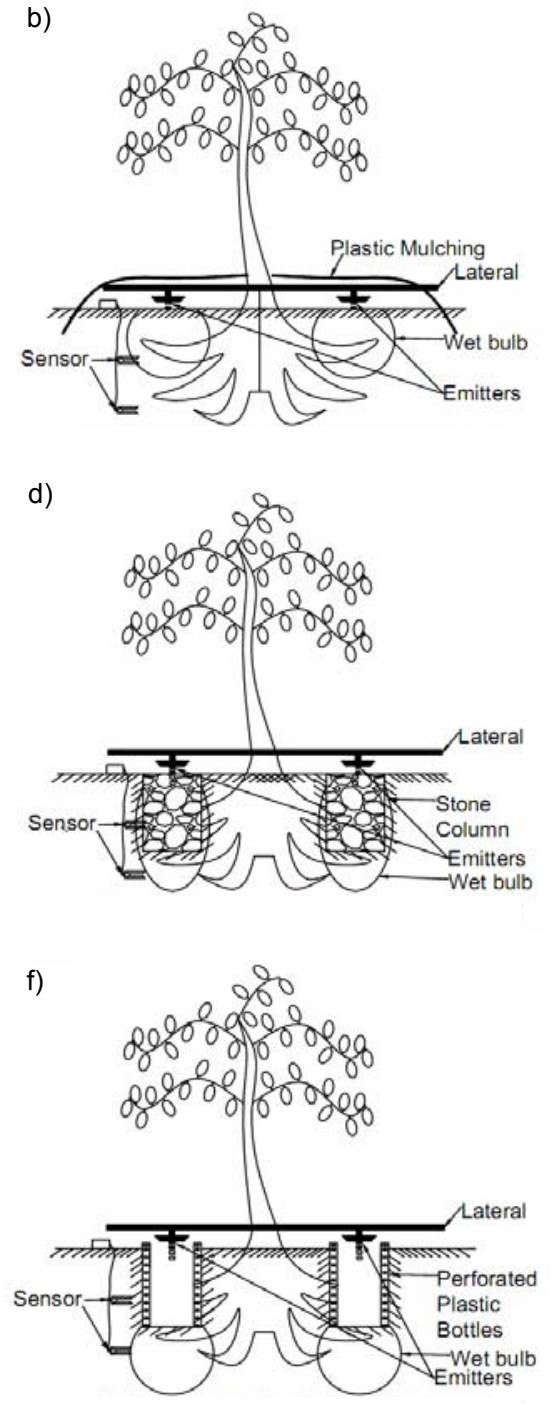

Fig. 1. Schemes of irrigation systems; a) drip irrigation (DI); b) drip irrigation with plastic mulching (DIPM); c) drip irrigation with organic mulching (DIOM); d) subsurface irrigation with the stone column (SISC); e) subsurface irrigation with mud pot (SIMP); f) subsurface irrigation with plastic bottles (SIPB); source: own elaboration

Figure 1e and Photo 1d. The wet bulb is formed below the mud pot i.e. $10 \mathrm{~cm}$ below the earth surface.

Subsurface irrigation with the plastic bottle (SIPB) irrigation system is the system in which perforated plastic bottles of $10 \mathrm{~cm}$ diameter and $30 \mathrm{~cm}$ deep inserted underground. Emitters are inserted at the top of the plastic bottle so that water reaches directly at root-zone. The clogging inspection of emitters is carried out easily. The plastic bottle is intentionally chosen as recycling of plastic material or disposing of waste plastic bottles is a global monster problem. Under these circumstances use of waste plastic bottles in a subsurface irrigation system may prove the efficient solution in solving the problems of recycling and disposal of plastic bottles, effective use of irrigation water supply and saving the environment as well. In this method, water reaches directly to the root zone of plant and reducing evaporation rate. This is shown in Figure 1f and Photo 1e. 

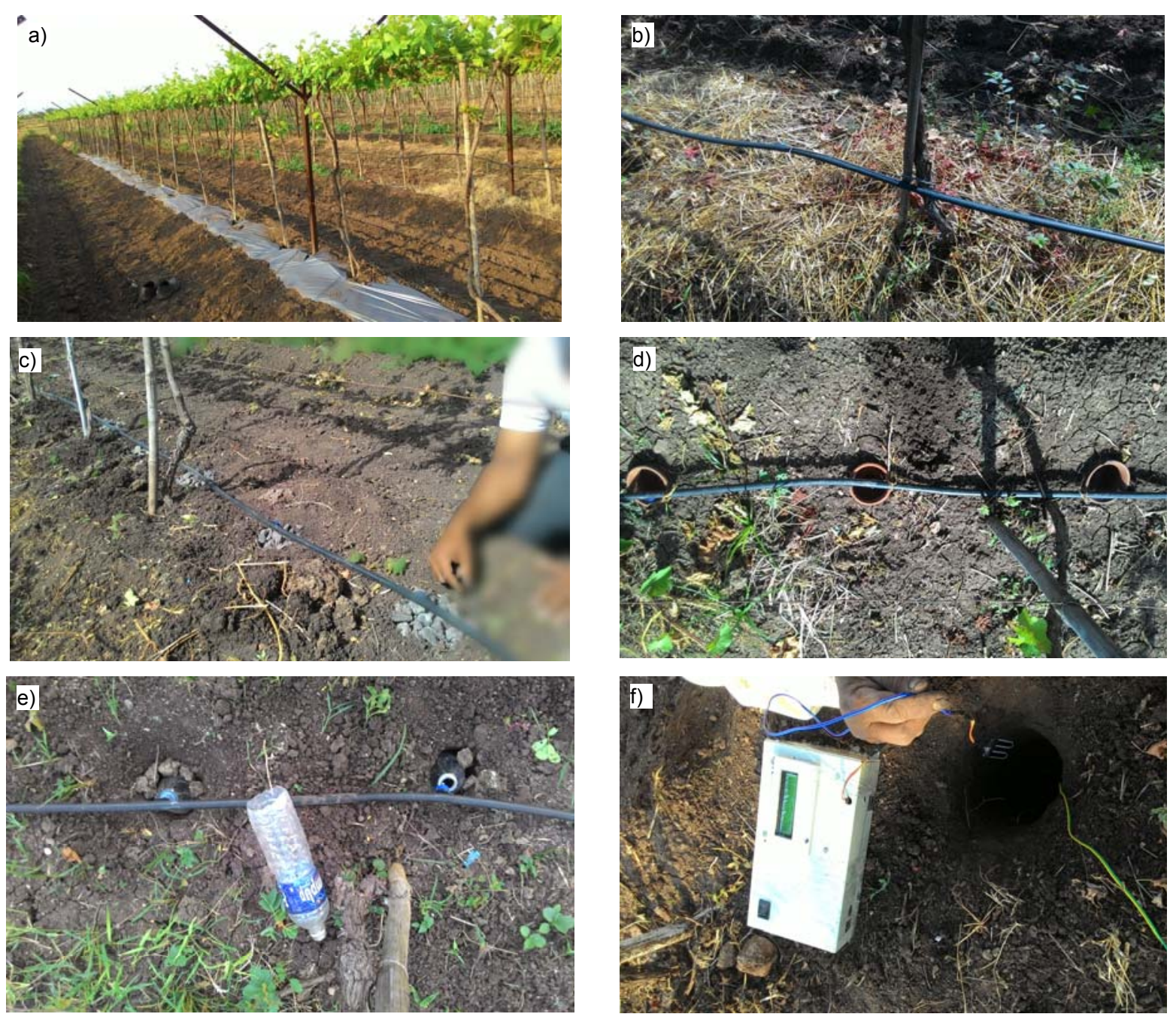

Photo 1. Photographic views of experimental work on the field: a) drip irrigation with plastic mulching (DIPM), b) drip irrigation with organic mulching (DIOM); c) subsurface irrigation stone column (SISC), d) subsurface irrigation with mud pot (SIMP), e) subsurface irrigation with plastic bottles (SIPB), f) moisture sensor and its recoding device (photo: S.J. Kadbhane)

\section{EVALUATION OF THE WATER REQUIREMENT USING CROPWAT-8.0 MODEL}

Management of irrigation is based on the knowledge of actual crop water use [GARCÍA, FERERES 2012]. The CROPWAT-8.0 model (developed by FAO) is used to calculate the water requirement of grape crop. The main purpose of use CROPWAT is to calculate irrigation scheduling and crop water demand on the basis of input of data provided by the user in the prescribed format [GHAMARNIA et al. 2011]. CROPWAT calculation procedures are based on FAO guidelines [ALLEN et al. 1998]. This allows the user to easily account for different soil, climatic and crop data in the calculation of crop water demand, irrigation schedules and scheme supplies [CONSOLI, BARBAGallo, 2012]. Penman-Monteith theory is used to calculate reference evapotranspiration (ETo). By using climatic, crop resistance and air resistance factors, evapotranspiration of the crop can be calculated with the help of Penman-Monteith approach. A PenmanMonteith is calculated the reference evapotranspira- tion (ETo) by the determined ratio of ETc/ETo experimentally called as crop coefficient $(K c)$, further it is used for estimating ETc from ETo. Crop evapotranspiration can be evaluated by

$$
E T c=E T o \cdot K c
$$

It is called as an approach of crop coefficient to evaluate the evapotranspiration of the crop. PenmanMonteith relation gives consistent performance and fairly accurate results in arid as well as humid climates. The FAO Penman-Monteith equation [ALLEN et al. 1998] mention as below:

$$
\text { ETo }=\frac{0.408 \Delta\left(R_{n}-G\right)+\gamma \frac{900}{T+273} u_{2}\left(e_{s}-e_{a}\right)}{\Delta+\gamma\left(1+0.34 u_{2}\right)}
$$

where: $E T o=$ reference evapotranspiration, $\mathrm{mm} \cdot \mathrm{day}^{-1}$; $G=$ the heat flux density of soil, $\mathrm{MJ} \cdot \mathrm{m}^{-2} \cdot$ day $^{-1} ; R_{n}=$ the net radiation at the crop surface, $\mathrm{MJ}_{\mathrm{m}} \mathrm{m}^{-2} \cdot \mathrm{day}^{-1}$; 
$T=$ mean of air temperature at $2 \mathrm{~m}$ height daily, ${ }^{\circ} \mathrm{C}$; $u_{2}=$ wind speed at $2 \mathrm{~m}$ height, $\mathrm{m} \cdot \mathrm{s}^{-1} ; \Delta=$ the slope of the vapour pressure curve, $\mathrm{kPa} \cdot{ }^{\circ} \mathrm{C}^{-1} ; e_{a}=$ the actual vapour pressure, $\mathrm{kPa} ; \gamma=$ the psychrometric constant, $\mathrm{kPa} \cdot{ }^{\circ} \mathrm{C}^{-1} ; e_{s}=$ the saturation vapour pressure, $\mathrm{kPa}$; $e_{s}-e_{a}=$ the deficit saturation vapour pressure, $\mathrm{kPa}$.

\section{PHENOLOGY OF GRAPE CROP}

$K c$ coefficient is varying with phenological stages, so water requirement varies accordingly. The grape crop is pruned twice in a year. First pruning is in the first week of April to germinate the bunch itself in tree branches. Second pruning is in the second week of October. The seasonal dynamics of $K c$ is affected due to an environmental condition (temperate vs tropical) and the age of the grape crop. The seasonal crop coefficients are different in two phases, 1 . $K c$ has increased during active growth to peak canopy size and 2. $K c$ is decreased during leaf senescence. The relationship of $K c$ and leaf area index cannot unique due to large variation in a canopy structure with pruning and training systems i.e. the link is different for decreasing or increasing of $K c$ [NETZER et al. 2009]. So according to theory mention above $K c$ value is changed according to the phenological stage, has taken as 0.4 for $0-25$ days after pruning, 0.7 for 26-149 days after pruning and 0.5 for $150-180$ days after pruning.

\section{SOIL MOISTURE MEASUREMENT USING SENSORS}

Two sensors at the different depth at the same location give more beneficial information than they place at the separate location [STEDUTO et al. 2012]. ECH2O of Decagon Devices capacitive sensors are mounted to soil moisture measurement. The resolutions of sensors are $0.002 \mathrm{~m}$ and have a margin of error of about $2 \%$ according to the manufacturer's declaration. Two $15-\mathrm{cm}$ probes are installed in each location.

As per Indian standards [IS:2720-2] Water/ moisture content of a soil mass is defined as the ratio of the mass of water in the voids to the mass of solids, as shown below in the equation (3)

$$
\theta_{v}=\frac{V_{w}}{V_{s}}
$$

where: $\theta_{v}=$ soil moisture $\left(\mathrm{m}^{3} \cdot \mathrm{m}^{-3}\right), V_{w}=$ the volume of water, $\mathrm{m}^{3} ; V_{s}=$ the volume of soil, $\mathrm{m}^{3}$.

The water content, which is usually expressed as a percentage, can range from zero (dry soil) to $30 \%$ (fully saturated soil). The natural water content of most soils is well under $15 \%$. Sensor probe output readings are calibrated using different moisture level range from the $100 \mathrm{~g}$ oven dried sample having $0 \%$ water content taken in 10 no of bolus and water is added $0-30 \%$ at the interval of $3 \%$. The sensor probe is inserted in each bowl and output device calibrate accordingly so ensuring the device for giving appropriate readings. After calibration, sensors are inserted at the shallow depth at $30 \mathrm{~cm}$, while the deeper sensor is placed at $60 \mathrm{~cm}$ or even deeper, depending on root depth. Sophisticated electronics instrument is given continuous records of soil moisture at several depths as shown in Photo 1f. Observations are taken periodically once in 2 days.

\section{IRRIGATION SCHEDULING}

By using CROPWAT result it is easy to decide the water requirement of the crop. There has the daily water requirement of the crop, but to reduce convenience losses and clogging of soil, irrigation is scheduled once in 5-6 days. Irrigation is scheduled mostly in the early morning period to reduce the surface evaporation losses during the summer. The farm pond is used for irrigation water supply. Water is lift using the $3 \mathrm{Hp}$ electric pump, through the $75 \mathrm{~mm}$ PVC pipeline. The laterals are attached to the pipeline. At the time of irrigation scheduling, water pressure is measured at the end of the lateral using pressure meter RODRÍGUEZ et al. [2009].

Water amount is calculated by the simple relationship, i.e. duration of drip irrigation by using the equation (4):

Duration of irrigation $(\mathrm{h})=\frac{R I \cdot P I \cdot N I R \cdot 1000}{E C \cdot N}$

where: $R I=$ the row interval, $\mathrm{m} ; P I=$ the plant interval, $\mathrm{m} ; N I R=$ the net irrigation requirement, $\mathrm{m} ; E C=$ irrigation capacity, $\mathrm{dm}^{3} \cdot \mathrm{h}^{-1} ; N=$ the number of emitters per plant.

\section{PROPERTIES OF SOIL}

Soil investigation is carried out using the field test. A pit of size $1 \times 1 \times 1.2 \mathrm{~m}$ is excavated to collect the soil. The initial available soil moisture is measured using non-disturbed soil sample from the experimental site using the core cutter and soil moisture measured using oven dry method and infiltration rate using a varying head permeability test. Chemical properties of soil are tested in the National Horticulture Research and Development Center (NHRDC), Bio-Chemistry Division, Nashik. As per testing report, properties are as given, $\mathrm{pH} 8.41$, electrical conductivity $0.232 \mathrm{dS} \cdot \mathrm{m}^{-1}$, organic carbon $0.99 \%$, available nitrogen $508.4 \mathrm{~kg} \cdot \mathrm{ha}^{-1}$, available phosphorus $25.50 \mathrm{~kg} \cdot \mathrm{ha}^{-1}$, available potash $336.0 \mathrm{~kg} \cdot \mathrm{ha}^{-1}$, available calcium $640 \mathrm{mg} \cdot \mathrm{kg}^{-1}$, available sodium 260 $\mathrm{mg} \cdot \mathrm{kg}^{-1}$, calcium carbonate $11.4 \%$, magnesium 288 $\mathrm{mg} \cdot \mathrm{kg}^{-1}$, chlorides $1.59 \mathrm{mg} \cdot \mathrm{kg}^{-1}$, sulphur $9.6 \mathrm{mg} \cdot \mathrm{kg}^{-1}$, copper $2.339 \mathrm{mg} \cdot \mathrm{kg}^{-1}$, iron $1.699 \mathrm{mg} \cdot \mathrm{kg}^{-1}$, manganese $2.220 \mathrm{mg} \cdot \mathrm{kg}^{-1}$, and zinc $0.6724 \mathrm{mg} \cdot \mathrm{kg}^{-1}$. 


\section{CROPPING TECHNIQUES}

All the cropping techniques such as tillage, pruning, fertilisers, pesticides and fungicides are common for all the methods. Tillage is done up to $10 \mathrm{~cm}$ deep once in summer using $18.5 \mathrm{Hp}$. tractors to protect cracking in soil surface. Organic like vermin compost and cow dung are use as fertilisers $5 \mathrm{~kg}$ per grape plant. Foundation pruning is carried out on $1^{\text {st }}$ April and fruit pruning is carried out 16 October. A Carbendazim-50\% WP and Copper hydroxide was use as fungicides and Diclorovos-50 is use as pesticides. Sometime plant manure use for spraying purpose.

\section{THE COST AND BENEFITS OF IRRIGATION SYSTEMS}

Irrigation water sources like well, farm pond and convinced system like pipeline, laterals, and emitters are common in all irrigation system. DI system is not required any addition material, so extra expenses have not indicated. The cost of material and labour is considered in the cost analysis subjected to market rates. In DIPM system, $1 \mathrm{~m}$ wide and 100-micron plastic paper is chosen for this system. In the DIOM system, organic material purchased from the organic producer agencies and the organic biomass after pruning is also used as organic mulching material.

Basalt rocks of size $2.5-3.0 \mathrm{~cm}$ sizes are purchased from nearby stone mining. Mud pots of $10 \mathrm{~cm}$ diameter have purchased for the SIMP system. Plastic bottles are purchased from scrap materials shop for the SIPB system. Plastic bottles are first cut from bottoms and making the perforations of 5 to $10 \mathrm{~mm}$ on the vertical surface of the bottle and then placed in the excavated pit.

The benefit of irrigation systems is calculated using percentage water saving in each irrigation system. The cost of water is considered subjected to market rates as per local water supply agencies at the time of water scarcity.

\section{MULTIFACTORIAL STATISTICS ANALYSIS}

Assessment of influences of considered factor on the dependent variables is carried out by multifactorial analysis using analysis of variance (ANOVA) method. Only evapotranspiration has considered in analysis to study its effect on the soil moisture level. In this analysis moisture level at the $30 \mathrm{~cm}$ and $60 \mathrm{~cm}$ depth with DI, DIPM, DIOM, SISC, SIMP, and SIPB system are selected as dependent variable and the irrigation water considered as independent variable. Statistical analysis is carried out using Microsoft Excel Statistical Analysis Pact-2010.

\section{RESULTS AND DISCUSSIONS}

\section{MEASUREMENT OF EVAPOTRANSPIRATION, NET WATER REQUIREMENTS}

Water requirement is varying with season, so it is planned during the summer $\left(01^{\mathrm{st}}\right.$ April to $30^{\text {th }}$ June $)$, rainy $\left(01^{\text {st }} \mathrm{July}\right.$ to $30^{\text {th }}$ October $)$ and winter $\left(01^{\text {st }} \mathrm{No}\right.$ vember to $30^{\text {th }}$ March) seasons using different irrigation methods and measured their effects on soil moisture. Climate data is collected on the daily basis from the Ozar (Nashik) weather station, which is located $2.1 \mathrm{~km}$ from experimental field. Precipitation mainly occurs in the months of July to October shown in the Table 1 . There are very high variations in effective precipitation as compared to reference evapotranspiration. Evapotranspiration is taken common for all irrigation systems so that it easy calculate the water requirement of the crop per day, but we can regulate provided water for the crop using sensor readings so that it is easy to find out the amount of water saving.

As evapotranspiration increases, net irrigation requirement also increases, but in the month of July to October irrigation requirement is fulfilling by precipitation. A net irrigation requirement is the difference of reference evapotranspiration and effective rainfall as shown in Figure $2 \mathrm{a}, \mathrm{b}$, c. Hence monthly water demands are varying and crop water demand is a maximum in summer i.e. April to June in the study area, as compared to rainy and the winter season.

Table 1. The seasonal climate and irrigation scheduling variables

\begin{tabular}{|c|c|c|c|c|c|c|}
\hline \multirow{2}{*}{ Season } & \multirow{2}{*}{ Period } & $E T c$ & $P_{e f}$ & NIR & $I W P$ & \multirow{2}{*}{$\begin{array}{l}\varepsilon \\
\%\end{array}$} \\
\hline & & \multicolumn{4}{|c|}{$\mathrm{mm}$} & \\
\hline \multirow{6}{*}{ 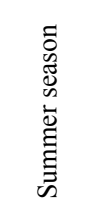 } & April & 55.1 & 1.7 & 53.5 & 60.0 & 5.73 \\
\hline & May & 82.6 & 0.6 & 81.9 & 90.0 & 4.71 \\
\hline & June & 78.7 & 10.0 & 68.0 & 70.0 & 1.44 \\
\hline & mean & 72.1 & 4.1 & 67.8 & 73.3 & 3.96 \\
\hline & $S D$ & 12.1 & 4.2 & 11.6 & 12.5 & 1.83 \\
\hline & $C V(\%)$ & 16.8 & 102.3 & 17.1 & 17.0 & 46.17 \\
\hline \multirow{7}{*}{ 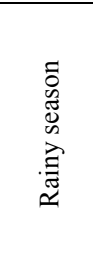 } & July & 65.5 & 80.3 & 8.0 & 10.0 & 11.11 \\
\hline & August & 55.2 & 57.2 & 0.0 & 0.0 & 0.00 \\
\hline & September & 31.8 & 138.7 & 5.6 & 7.0 & 11.11 \\
\hline & October & 45.9 & 49.6 & 7.8 & 10.0 & 12.36 \\
\hline & mean & 49.6 & 81.5 & 5.4 & 6.8 & 8.65 \\
\hline & $S D$ & 12.4 & 34.9 & 3.2 & 4.1 & 5.02 \\
\hline & $C V(\%)$ & 25.0 & 42.9 & 60.4 & 60.5 & 58.04 \\
\hline \multirow{8}{*}{ 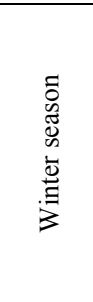 } & November & 54.2 & 9.0 & 45.3 & 50.0 & 4.93 \\
\hline & December & 56.0 & 0.1 & 55.9 & 60.0 & 3.54 \\
\hline & January & 55.8 & 0.0 & 55.8 & 60.0 & 3.63 \\
\hline & February & 54.4 & 0.1 & 54.2 & 60.0 & 5.08 \\
\hline & March & 39.7 & 9.7 & 30.1 & 35.0 & 7.53 \\
\hline & mean & 52.0 & 3.8 & 48.3 & 53.0 & 4.90 \\
\hline & $S D$ & 6.2 & 4.6 & 9.9 & 9.8 & 1.40 \\
\hline & $C V(\%)$ & 11.9 & 120.5 & 20.5 & 18.5 & 29.20 \\
\hline
\end{tabular}

Explanations: $E T c=$ reference evapotranspiration at standard conditions; $P_{e f}=$ total monthly rainfall; $N I R=$ net irrigation requirements; $I W P=$ irrigation water provided to the field; $\varepsilon=$ relative deviation between IWP and NIR. SD = standard deviation; $C V(\%)=$ coefficient of variation.

Source: own study. 

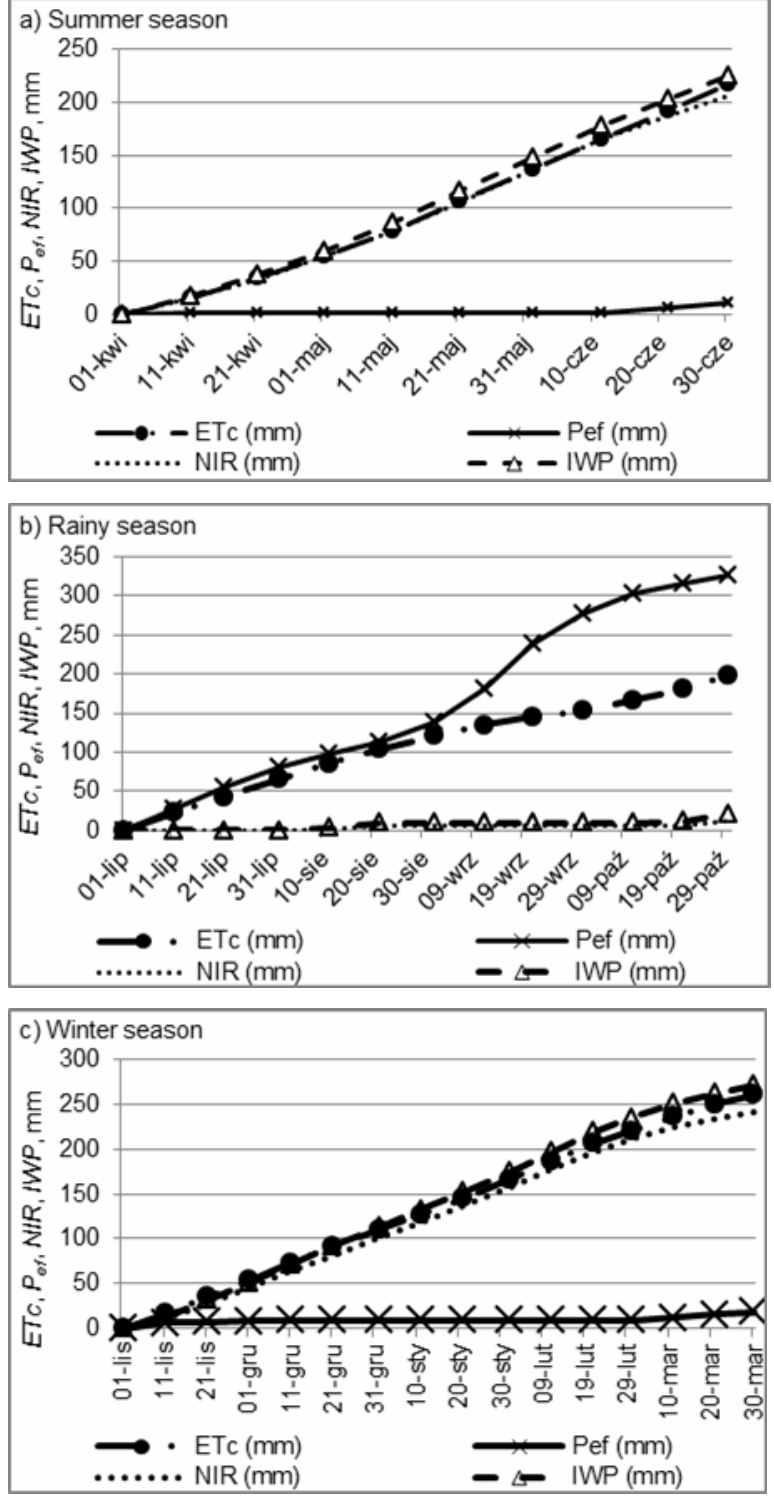

Fig. 2. Time series of irrigation scheduling variables; $E T c=$ crop evapotranspiration, $P e f=$ total monthly rainfall, $N I R=$ net irrigation requirements, $I W P=$ irrigation water provided to the field; source: own study

\section{EXPERIMENTAL DATA OF SOIL MOISTURE}

Table 2 shows the mean values of recorded soil moisture data of the $30 \mathrm{~cm}$ and $60 \mathrm{~cm}$ depth for three seasons. From the Table 2, it is observed that in the DI system found large variation in the observed data. The value $C V$ is $40.7 \%$ in the summer season, which is a maximum of all systems. Whereas, in the DIPM system observed value $C V$ soil moisture is $6.1 \%$ in the summer season, which is very low. The DIOM, SIMP, SISC, SIPB systems show maximum variation in data in the rainy season, due to the occurrence of rainfall. High variation in recorded data indicates the sudden decreasing in moisture level. So the DIPM system is showing low moisture variation in all the three season as compared to the other irrigation systems, the SIPB system is also showing low moisture variation in all the three season as compared to the other irrigation systems and high as compared to DIPM. So it is suitable to maintain the soil moisture level by using DIPM and SIPB irrigation systems.

Figure $3 \mathrm{a}, \mathrm{b}$, c shows the box plot of recorded data for the surface and subsurface irrigation system. From the above plot, it is observed that in case of the surface irrigation system, the large variation of data is seen in the DI system, which is the lowest soil moisture up to $3.25 \%$ and maximum time, it is below the average level. Where DIPM is shown the maximum soil moisture level up to $18-19 \%$ and very less variation of data. The DIOM system is more variations in soil moisture as compared to the DIPM system. It means that for the surface irrigation system DIPM system is more beneficial to retain soil moisture among two mulching systems in all three seasons. Whereas in the subsurface irrigation SIPB system is shown 16-19\% moisture levels, and it is maximum as compared to the other subsurface irrigation system in three seasons. DIPM is showing the highest value soil moisture retention among surface irrigation systems, and the SIPB showing the highest retention among the subsurface irrigation systems in all the three seasons.

Table 2. Experimental mean data of soil moisture (\%) for six irrigation systems at the depth of 60 and $30 \mathrm{~cm}$

\begin{tabular}{|c|c|r|r|r|r|r|r|r|r|r|r|r|r|r|r|r|}
\hline \multirow{2}{*}{ Season } & \multirow{2}{*}{ Parameter } & \multirow{2}{*}{$E T C$} & \multicolumn{2}{|c|}{ DI } & \multicolumn{2}{|c|}{ DIPM } & \multicolumn{2}{|c|}{ DIOM } & \multicolumn{2}{|c|}{ SISC } & \multicolumn{3}{|c|}{ SIMP } & \multicolumn{2}{c|}{ SIPB } \\
\cline { 4 - 14 } & & & $30 \mathrm{~cm}$ & $60 \mathrm{~cm}$ & $30 \mathrm{~cm}$ & $60 \mathrm{~cm}$ & $30 \mathrm{~cm}$ & $60 \mathrm{~cm}$ & $30 \mathrm{~cm}$ & $60 \mathrm{~cm}$ & $30 \mathrm{~cm}$ & $60 \mathrm{~cm}$ & $30 \mathrm{~cm}$ & $60 \mathrm{~cm}$ \\
\hline \multirow{4}{*}{ Summer } & mean & 2.4 & 0.20 & 0.19 & 0.33 & 0.31 & 0.28 & 0.25 & 0.24 & 0.29 & 0.25 & 0.23 & 0.25 & 0.30 \\
& $S D$ & 1.0 & 0.05 & 0.08 & 0.02 & 0.03 & 0.04 & 0.05 & 0.07 & 0.03 & 0.07 & 0.05 & 0.06 & 0.04 \\
& $C V$ & 42.6 & 27.78 & 40.69 & 6.15 & 8.08 & 16.02 & 19.04 & 27.80 & 9.05 & 28.85 & 20.65 & 22.58 & 13.84 \\
\hline \multirow{4}{*}{ Rainy } & mean & 1.6 & 0.22 & 0.24 & 0.29 & 0.26 & 0.23 & 0.22 & 0.19 & 0.20 & 0.19 & 0.19 & 0.21 & 0.23 \\
& $S D$ & 0.4 & 0.06 & 0.06 & 0.03 & 0.04 & 0.06 & 0.06 & 0.08 & 0.06 & 0.09 & 0.08 & 0.09 & 0.05 \\
& $C V$ & 25.1 & 28.77 & 23.53 & 9.26 & 16.86 & 26.86 & 28.04 & 44.11 & 30.88 & 48.07 & 42.04 & 42.60 & 22.03 \\
\hline \multirow{3}{*}{ Winter } & mean & 1.7 & 0.27 & 0.25 & 0.30 & 0.30 & 0.26 & 0.24 & 0.24 & 0.22 & 0.24 & 0.22 & 0.25 & 0.26 \\
& $S D$ & 0.3 & 0.03 & 0.04 & 0.02 & 0.04 & 0.04 & 0.05 & 0.05 & 0.05 & 0.05 & 0.06 & 0.05 & 0.04 \\
& $C V$ & 15.8 & 12.10 & 18.09 & 6.65 & 12.93 & 14.84 & 20.17 & 18.84 & 22.97 & 18.90 & 26.78 & 19.62 & 14.12 \\
\hline
\end{tabular}

Explanations: DI = drip irrigation, DIPM = drip irrigation with plastic mulching, DIOM = drip irrigation with organic mulching, SISC $=$ subsurface irrigation with the stone column, SIMP = subsurface irrigation with mud pot, SIPB = subsurface irrigation with plastic bottles, $S D=$ standard deviation, $C V=$ coefficient of variation in $\%$.

Source: own study. 

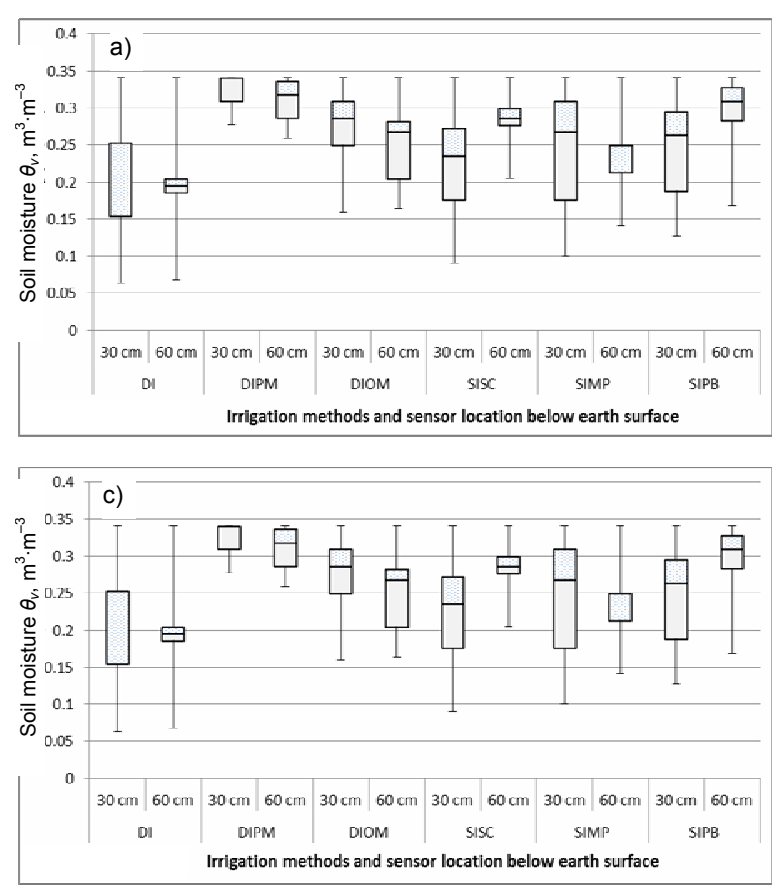

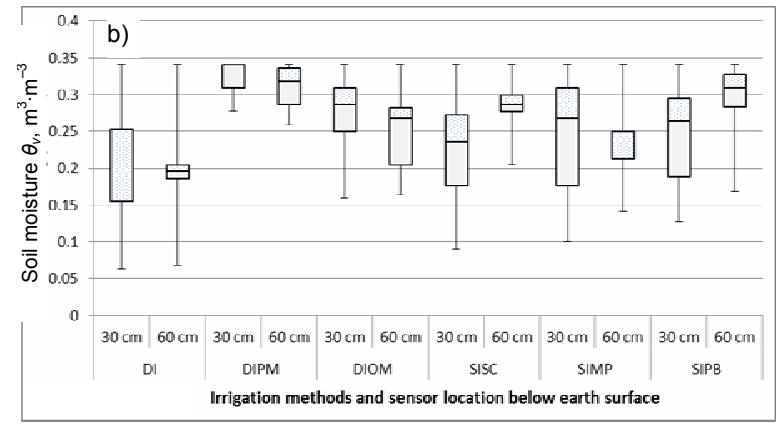

Fig. 3. Box plot of recorded moisture data: a) summer season, b) rainy season, c) winter season; DI, DIPM, DIOM, SISC, SIMP, SIPB as under the Table 2; source: own study
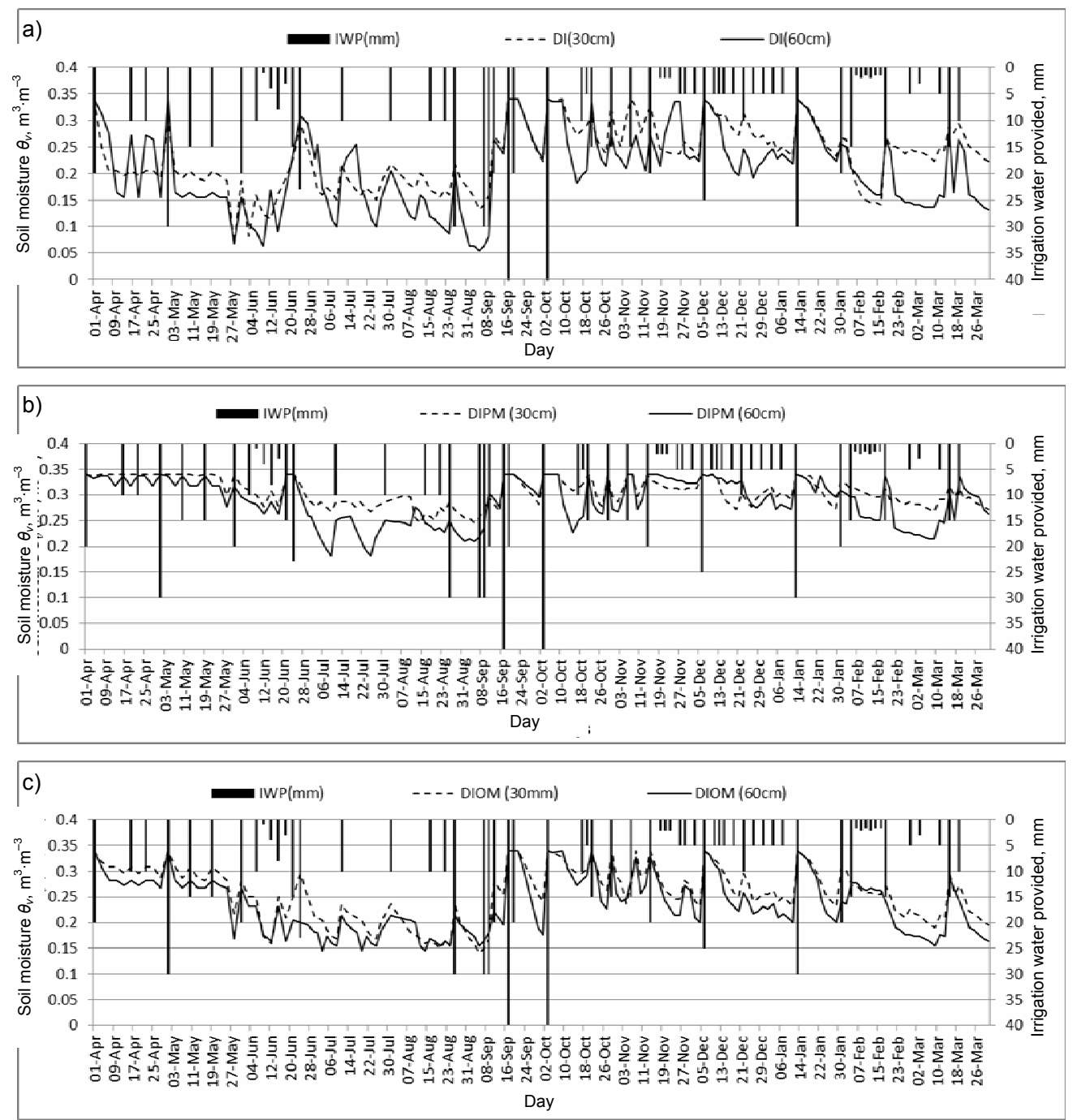

Fig. 4. Graphical representation of measured soil moisture at the depth $30 \mathrm{~cm}$ and $60 \mathrm{~cm}$ in: a) drip irrigation (DI); b) drip stone column (SISC); e) subsurface irrigation with mud pot (SIMP); f) subsurface irrigation with plastic bottles (SIPB); 


\section{AN IMPACT OF IRRIGATION SYSTEMS ON SOIL MOISTURE}

Figure 4 indicates the periodical variations in soil moisture with respect to time and irrigation water provided periodically using different irrigation systems throughout three seasons. In the month of April and May moisture level is continuously maintained using irrigation. In the month of July and August moisture level is decrease constantly because of low precipitation, scarcity of water and high evapotranspiration. In the month of September, there is a sudden increase in moisture level due to precipitation occurs. In the months of October to January, there is continuous high moisture level due to fruit pruning and application of irrigation water. In the month of February and March, moisture level is decreased purposely to increase the berry sugar.

An impact of DI irrigation systems on soil moisture. Table 3 shows the results of multifactorial analysis of variance of soil moisture for the summer season. In the case of DI system, statistical analysis shows 5\% significance level $(P$-value $<0.05)$ interac- tion between moisture at depth $30 \mathrm{~cm}$ and $60 \mathrm{~cm}$ as well as soil moisture and water requirement. Evapotranspiration is shown the significant impact on soil moisture. Figure $4 \mathrm{a}$ indicates the periodical variations in soil moisture with respect to time and irrigation water provided periodically using the DI system throughout three seasons. $95 \%$ confidence interval is obtained for the period of summer seasons for the 30 $\mathrm{cm}$ and $60 \mathrm{~cm}$ depth probe, but in case of the rainy and winter season $60 \mathrm{~cm}$ probe readings not showing the $95 \%$ significance level. $30 \mathrm{~cm}$ depth probe is sometimes showing less moisture level as compared to the $60 \mathrm{~cm}$ depth probe.

An impact of the DIPM system on soil moisture. Table 3 shows the results of multifactorial analysis for the DIPM system. Statistical analysis shows the $5 \%$ significance level $(P$-value $<0.05)$ interaction between moisture at both depth $30 \mathrm{~cm}$ and $60 \mathrm{~cm}$ as well as soil moisture and water requirement. Fig. $4 \mathrm{~b}$ indicates there are no periodical variations in soil moisture with respect to time and irrigation water provided periodically using the DIPM system. 95\%
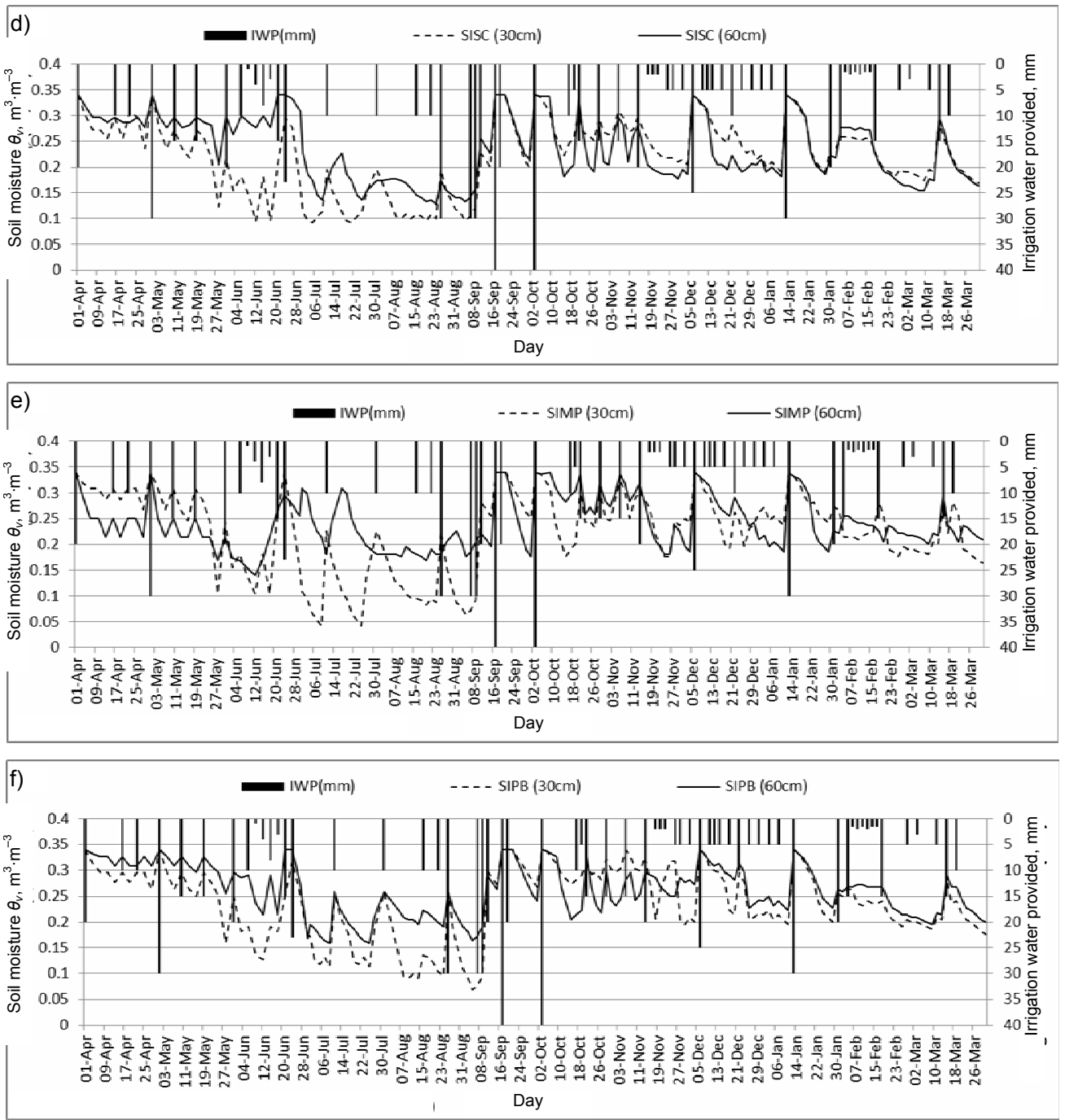

irrigation with plastic mulching (DIPM); c) drip irrigation with organic mulching (DIOM); d) subsurface irrigation with the source: own study 
Table 3. Analysis of variance of DI, DIPM, DIOM, SISC, SIMP, SIPB systems for soil moisture

\begin{tabular}{|c|c|c|c|c|c|c|c|c|c|c|c|c|c|c|c|}
\hline \multirow{2}{*}{ Source } & \multicolumn{5}{|c|}{ Summer season } & \multicolumn{5}{|c|}{ Rainy season } & \multicolumn{5}{|c|}{ Winter season } \\
\hline & $D f$ & $S S$ & $M S$ & $F$-ratio & $P$-value & $D f$ & SS & $M S$ & $F$-ratio & $P$-value & $D f$ & SS & $M S$ & $F$-ratio & $P$-value \\
\hline \multicolumn{16}{|c|}{ Drip irrigation (DI) } \\
\hline \multicolumn{16}{|c|}{ Main effects } \\
\hline $\mathrm{A}: 30 \mathrm{~cm}$ & 1 & 0.022 & 0.022 & 9.1 & 0.01 & 1 & 1.45 & 1.45 & 30.6 & 0.0 & 1 & 0.105 & 0.105 & 6.5 & 0.01 \\
\hline B: $60 \mathrm{~cm}$ & 1 & 0.061 & 0.061 & 13.7 & 0.0 & 1 & 0.17 & 0.17 & 3.1 & 0.09 & 1 & 0.037 & 0.037 & 1.2 & 0.29 \\
\hline \multicolumn{16}{|l|}{ Interact } \\
\hline $\mathrm{AB}$ & 1 & 0.130 & 0.130 & 63.6 & 0.0 & 1 & 2.03 & 2.03 & 89.1 & 0.0 & 1 & 1.120 & 1.120 & 465 & 0.0 \\
\hline Residual & 29 & 0.059 & 0.002 & - & - & 60 & 1.36 & 0.02 & - & - & 74 & 0.178 & 0.002 & - & - \\
\hline Total & 30 & 0.189 & - & - & - & 61 & 3.39 & - & - & - & 75 & 1.297 & - & - & - \\
\hline \multicolumn{16}{|c|}{ Drip irrigation with plastic mulching (DIPM) } \\
\hline \multicolumn{16}{|c|}{ Main effects } \\
\hline A: $30 \mathrm{~cm}$ & 1 & 0.00 & 0.002 & 6.2 & 0.01 & 1 & 0.11 & 0.11 & 10.1 & 0.002 & 1 & 0.062 & 0.062 & 10.4 & 0.002 \\
\hline B: $60 \mathrm{~cm}$ & 1 & 0.00 & 0.005 & 9.3 & 0.00 & 1 & 0.80 & 0.80 & 39.2 & 0.000 & 1 & 0.051 & 0.051 & 2.2 & 0.043 \\
\hline \multicolumn{16}{|l|}{ Interact } \\
\hline $\mathrm{AB}$ & 1 & 0.01 & 0.018 & 232 & 0.00 & 1 & 1.22 & 1.22 & 91.8 & 0.000 & 1 & 0.829 & 0.829 & 65.1 & 0.000 \\
\hline Residual & 29 & 0.00 & 0.000 & - & - & 60 & 0.80 & 0.01 & - & - & 74 & 0.942 & 0.013 & - & - \\
\hline Total & 30 & 0.02 & - & - & - & 61 & 2.02 & - & - & - & 75 & 1.771 & - & - & - \\
\hline \multicolumn{16}{|c|}{ Drip irrigation with organic mulching (DIOM) } \\
\hline \multicolumn{16}{|c|}{ Main effects } \\
\hline A: $30 \mathrm{~cm}$ & 1 & 0.017 & 0.017 & 11.6 & 0.002 & 1 & 1.14 & 1.14 & 23.42 & 0.000 & 1 & 0.302 & 0.302 & 14.6 & 0.000 \\
\hline B: $60 \mathrm{~cm}$ & 1 & 0.018 & 0.018 & 10.0 & 0.004 & 1 & 1.04 & 1.04 & 20.65 & 0.000 & 1 & 0.460 & 0.460 & 14.4 & 0.000 \\
\hline \multicolumn{16}{|l|}{ Interact } \\
\hline $\mathrm{AB}$ & 1 & 0.060 & 0.060 & 155 & 0.000 & 1 & 3.56 & 3.56 & 440.6 & 0.000 & 1 & 1.632 & 1.632 & 592 & 0.000 \\
\hline Residual & 29 & 0.011 & 0.000 & - & - & 60 & 0.49 & 0.01 & - & - & 74 & 0.204 & 0.003 & - & - \\
\hline Total & 30 & 0.071 & 0 & - & - & 61 & 4.05 & - & - & - & 75 & - & - & - & - \\
\hline \multicolumn{16}{|c|}{ Subsurface irrigation with stone column (SISC) } \\
\hline \multicolumn{16}{|c|}{ Main effects } \\
\hline $\mathrm{A}: 30 \mathrm{~cm}$ & 1 & 0.04 & 0.046 & 15 & 0.00 & 1 & 2.61 & 2.61 & 37.4 & 0.00 & 1 & 0.3 & 0.30 & 10.3 & 0.002 \\
\hline B: $60 \mathrm{~cm}$ & 1 & 0.00 & 0.002 & 3.0 & 0.09 & 1 & 1.22 & 1.22 & 24.0 & 0.00 & 1 & 0.2 & 0.27 & 6.8 & 0.011 \\
\hline \multicolumn{16}{|l|}{ Interact } \\
\hline $\mathrm{AB}$ & 1 & 0.00 & 0.007 & 13 & 0.00 & 1 & 3.30 & 3.30 & 207. & 0.00 & 1 & 2.6 & 2.68 & 357. & 0.000 \\
\hline Residual & 29 & 0.01 & 0.001 & - & - & 60 & 0.95 & 0.02 & & & 74 & 0.5 & 0.01 & - & - \\
\hline Total & 30 & 0.02 & - & - & - & 61 & 4.26 & - & - & - & 75 & 3.2 & - & - & - \\
\hline & & & & & Subsurfa & ir & gation & ith $\mathrm{m}$ & Id pot ( & SIMP) & & & & & \\
\hline Main effec & & & & & & & & & & & & & & & \\
\hline A: $30 \mathrm{~cm}$ & 1 & 0.055 & 0.055 & 14.4 & 0.00 & 1 & 3.58 & 3.58 & 41.3 & 0.000 & 1 & 0.23 & 0.23 & 7.3 & 0.009 \\
\hline B: $60 \mathrm{~cm}$ & 1 & 0.019 & 0.019 & 10.6 & 0.002 & 1 & 1.28 & 1.28 & 13.5 & 0.001 & 1 & 0.46 & 0.46 & 8.8 & 0.004 \\
\hline Interact & & & & & & & & & & & & & & & \\
\hline $\mathrm{AB}$ & 1 & 0.040 & 0.040 & 37.7 & 0.00 & 1 & 7.14 & 7.14 & 262 & 0.000 & 1 & 1.39 & 1.39 & 88.9 & 0.000 \\
\hline Residual & 29 & 0.031 & 0.001 & - & - & 60 & 1.64 & 0.03 & - & - & 74 & 1.15 & 0.02 & - & - \\
\hline Total & 30 & 0.071 & 0.000 & - & - & 61 & 8.78 & - & - & - & 75 & 2.54 & - & - & - \\
\hline & & & & Sub & bsurface & irrig & ion w & plas & ic bottl & es (SIPB & & & & & \\
\hline Main effec & & & & & & & & & & & & & & & \\
\hline A: $30 \mathrm{~cm}$ & 1 & 0.03 & 0.035 & 15.0 & 0.00 & 1 & 2.42 & 2.42 & 25.8 & 0.000 & 1 & 0.28 & 0.281 & 8.2 & 0.005 \\
\hline B: $60 \mathrm{~cm}$ & 1 & 0.01 & 0.010 & 6.4 & 0.01 & 1 & 1.02 & 1.02 & 34.8 & 0.000 & 1 & 0.25 & 0.251 & 13.4 & 0.000 \\
\hline Interact & & & & & & & & & & & & & & & \\
\hline $\mathrm{AB}$ & 1 & 0.030 & 0.038 & 75.8 & 0.00 & 1 & 2.08 & 2.08 & 177 & 0.000 & 1 & 0.90 & 0.901 & 90.6 & 0.000 \\
\hline Residual & 29 & 0.015 & 0.001 & - & - & 60 & 0.70 & 0.01 & - & - & 74 & 0.73 & 0.010 & - & - \\
\hline Total & 30 & 0.053 & 0.000 & - & - & 61 & 2.78 & - & - & - & 75 & 1.63 & - & - & - \\
\hline
\end{tabular}

Explanations: $D f=$ degree of freedom, $S S=$ sum of squares, $M S=$ mean square, $P$-value = significance.

Source: own study.

confidence interval is obtaining for the period of three seasons for the $30 \mathrm{~cm}$ and $60 \mathrm{~cm}$ depth. A $30 \mathrm{~cm}$ depth probe is always showing greater moisture level as compared to the $60 \mathrm{~cm}$ depth probe. This high moisture retention capacity is due to the plastic mulching cover temperature of surface soil always less and so evaporated rate always less. The moisture is always maintained at the depth of $30 \mathrm{~cm}$, but it de- creases in the $60 \mathrm{~cm}$ depth due root zone. The DIPM system is saving up 25-30\% soil moisture as compared to DI system. So there is no possibility of the creation of stress on grape plants.

An impact of the DIOM system on soil moisture. Table 3 is indicating the results of multifactorial analysis of variance for observed values of soil moisture in the DIOM system. The results are statistically 
significant because of statistical analysis shows the $5 \%$ significance level $(P$-value $<0.05)$ interaction between moisture at both depth $30 \mathrm{~cm}$ and $60 \mathrm{~cm}$ as well as soil moisture and water requirement. Figure $4 \mathrm{c}$ is showing the periodical variations in soil moisture with respect to the time and irrigation water provided in the DIOM system. The $30 \mathrm{~cm}$ depth and $60 \mathrm{~cm}$ depth sensors are showing 95\% confidence interval obtained for soil moisture at the period of three seasons.

$30 \mathrm{~cm}$ depth probe is always showing greater moisture value as compared to the $60 \mathrm{~cm}$ depth probe. Moisture retention capacity is near about $10-12 \%$ less as compared to the plastic mulching because evaporation can't stop completely. There are chances to pass air from organic matters. So this system is less effective for moisture retention as compared to DIPM, but better than plain DI method because it is saving 13$18 \%$ more water than DI system.

An impact of SISC system on soil moisture. Table 3 shows the results of multifactorial analysis of variance of soil moisture in SISC system. Statistical analysis shows the 5\% significance level ( $P$-value $<0.05)$ in the moisture observation at depth $30 \mathrm{~cm}$ and $60 \mathrm{~cm}$ soil moisture values are not significant $(P$-value $>0.05)$. Whereas the interaction result shows the $95 \%$ significant level in all season except $60 \mathrm{~cm}$ probe results in the summer season. Figure $4 \mathrm{~d}$ indicates the periodical variations in soil moisture with respect to time and irrigation water provided periodically using the SISC system. $30 \mathrm{~cm}$ depth probe is always showing the smaller moisture level as compared to the $60 \mathrm{~cm}$ depth probe. It means due to the SISC system water provided directly at the root zone. The $60 \mathrm{~cm}$ depth sensor indicates that there is 10 $12 \%$ water saving as compared to the DI system.

An impact of the SIMP system on soil moisture. Table 3 indicated the results of multifactorial analysis of variance for observed values of soil moisture in the SIMP system. The results are statistically significant because of statistical analysis shows the 5\% significance level $(P$-value $<0.05)$ interaction between moisture at both depth $30 \mathrm{~cm}$ and $60 \mathrm{~cm}$ as well as soil moisture and water requirement.
The Figure $4 \mathrm{e}$ is shown periodical variations in soil moisture with respect to time and irrigation water provided in the SIMP system. 95\% confidence interval obtained for the period of three seasons for the 30 $\mathrm{cm}$ and $60 \mathrm{~cm}$ depth. A $30 \mathrm{~cm}$ depth probe is most of the time showing greater moisture value as compared to the $60 \mathrm{~cm}$ probe. It is clear that the SIMP system can't behave like the subsurface irrigation system because in the subsurface irrigation system $60 \mathrm{~cm}$ probe always shows greater value. Moisture retention capacity is about $6-10 \%$ more as compared to DI.

An impact of the SIPB system on soil moisture. Table 3 indicated the results of multifactorial analysis of variance for observed values of soil moisture in the SIPB system. The results are statistically significant because of statistical analysis shows the $5 \%$ significance level $(P$-value $<0.05)$ interaction between moisture at both depth $30 \mathrm{~cm}$ and $60 \mathrm{~cm}$ as well as soil moisture and water requirement. Figure $4 \mathrm{f}$ indicates the periodical variations in soil moisture with respect to time and irrigation water provided periodically using the SIPB system. Variation in observed data is less as compare to other subsurface methods. $30 \mathrm{~cm}$ depth probe is always showing smaller moisture level as compared to the $60 \mathrm{~cm}$ depth probe. It means is that due to SIPB system water provided directly at the root zone. The $60 \mathrm{~cm}$ depth sensor indicates that there is $15-20 \%$ water saving as compared to the DI system.

\section{BENEFIT-COST ANALYSIS OF IRRIGATION SYSTEMS}

The cost each irrigation system is calculated using material and labour charges. Drip laterals and emitters are common in all irrigation systems, so this analysis is apart from drip materials. Benefit is calculating using the amount of water saving. Water costs are 100 Indian Rupees (INR) $\mathrm{M}^{-3}$. Accordingly, benefit-cost analysis for each irrigation system is carried out as shown in Table 4. The SIPB system shows the highest 11.81 value of the benefit cost ratio, where DIPM system shows 4.88 , i.e. these two systems are economically viable as compared to other methods.

Table 4. Benefit - cost analysis of irrigation systems

\begin{tabular}{|c|c|c|c|c|c|}
\hline Cost per plant & DIPM & DIOM & SISC & SIMP & SIPB \\
\hline 1. The gross cost of material, INR & 3.00 & 6.00 & 10.00 & 20.00 & 4.00 \\
\hline 2. Labour charges, INR & 3.00 & 5.00 & 20.00 & 7.00 & 12.00 \\
\hline 3. Sum of material and labour, INR (row $1+$ row 2 ) & 6.00 & 11.00 & 30.00 & 27.00 & 16.00 \\
\hline 4. Life of materials, years & 1.00 & 1.00 & 6.00 & 5.00 & 10.00 \\
\hline 5. The total cost per year, INR (row 3/row 4) & 6.00 & 11.00 & 5.00 & 5.40 & 1.60 \\
\hline 6. Net water saving per year, $\%$ & $25-30$ & $13-18$ & $10-12$ & $6-10$ & $15-20$ \\
\hline 7. Net water saving per year, $\mathrm{m}^{3}$ & 0.283 & 0.170 & 0.113 & 0.945 & 0.189 \\
\hline 8. The total benefit through the net water saving per year, INR & 28.35 & 17.01 & 11.34 & 9.45 & 18.9 \\
\hline 9. Benefit cost ratio (row $8 /$ row 5 ) & 4.88 & 1.55 & 2.27 & 1.75 & 11.81 \\
\hline
\end{tabular}

Explanations: INR = Indian Rupees, DI, DIPM, DIOM, SISC, SIMP, SIPB as under the Table 2.

Source: own study. 


\section{CONCLUSIONS}

Based on the experiment carried out in summer, rainy, and winter seasons, it is observed that the moisture-retention level in the DIPM system found greatest among all systems of irrigation under the study period. The moisture level is maintained to $25-30 \%$ greater than the regular drip irrigation system. This increase in soil moisture retention level is due plastic cover which acts as temperature resisting material. The benefit-cost ratio is observed to be 4.88 for the same system, which is moderate among its class.

Subsurface irrigation with plastic bottles (SIPB) is showing higher soil moisture retention level as compared to other subsurface irrigation systems in all three season. The moisture level is maintaining 15 $20 \%$ greater than the regular drip irrigation system. This increase in soil moisture level is due to application of water directly to the root zone, so evaporation from surface soil is prevented. The benefit-cost ratio is observed to be 11.81 for the same system which is highest among its class. Hence it is recommended to use the SIPB irrigation system because it is water efficient, most economical and helps in recycling the plastic waste.

\section{ACKNOWLEDGMENTS}

"ATMA - Maharashtra Agriculture department, India, and Water Users Association, Maharashtra Irrigation department, India" has given support this work. Authors are thankful to the chairman and all members of the ATMA for their extended support and inspiration to carry out this work. Authors are also grateful to Indian Metrological Department Pune to support this study by sharing valuable data and information.

\section{REFERENCES}

Allen R., Pereira L.S., Raes D., Smith M., 1998. Crop evapotranspiration. Guidelines for computing crop water requirements. Irrigation and Drainage Paper. No. 56. Rome. FAO. ISBN 92-5-104219-5 pp. 300.

AragüÉs R., Medina E.T., Claveria I., Martínez-CoB A., FACI J. 2014. Regulated deficit irrigation, soil salinization and soil sodification in a table grape vineyard dripirrigated with moderately saline waters. Agricultural Water Management. Vol. 134 p. 84-93.

Ayars J.E., Phene C.J., Hutmacher R.B., Davis K.R., Schoneman R.A., VAIL S.S., MEAD R.M. 1999. Subsurface drip irrigation of row crops: A review of 15 years of research at the Water Management Research Laboratory. Agricultural Water Management. Vol. 42. Iss. 1 p. $1-27$.

Consoli S., Barbagallo S. 2012. Estimating water requirements of an irrigated mediterranean vineyard using a satellite-based approach. Journal of Irrigation and Drainage Engineering. Vol. 138. Iss. 10 p. 896-904.

Du T., KANG S., Zhang J., Li F., YAN B. 2008. Water use efficiency and fruit quality of table grape under alternate partial root-zone drip irrigation. Agricultural Water Management. Vol. 95. Iss. 6 p. 659-668.

Faci J.M., Blanco O., Medina E.T., Martínez-Cob A. 2014. Effect of post veraison regulated deficit irrigation in production and berry quality of Autumn Royal and Crimson table grape cultivars. Agricultural Water Management. Vol. 134 p. 73-83.

García-Vila M., Fereres E. 2012. Combining the simulation crop model AquaCrop with an economic model for the optimization of irrigation management at farm level. European Journal of Agronomy. Vol. 36. Iss. 1 p. 21-31.

Ghamarnia H., ArJi I., SePehri S., NorozPour S., KhODAEI E. 2011. Evaluation and comparison of drip and conventi onal irrigation methods on sugar beets in a semiarid region. Journal of Irrigation and Drainage Engineering. Vol. 138. Iss. 1 p. 90-97.

Government of India 2014. Hand book on horticulture statistics 2014. New Delhi. Ministry of Agriculture Department of Agriculture and Cooperation pp. 34.

IPCC 2007. An assessment of the Intergovernmental Panel on Climate Change. Climate Change: Synthesis Report. 4 p. $26-40$.

IS:2720-2 1973. Methods of test for soils. P.2: Determination of water content. Second revision. New Delhi. Bureau of Indian Standards pp. 18.

LaZarovitch N., Shani U., ThOMPson T., Warrick A. 2006. Soil hydraulic properties affecting discharge uniformity of gravity-fed subsurface drip irrigation systems. Journal of Irrigation and Drainage Engineering. Vol. 132. Iss. 6. DOI: 10.1061/(ASCE)0733-9437 (2006)132:6(531) p. 531-536.

MARTíneZ J., RECA J. 2014. Water use efficiency of surface drip irrigation versus an alternative subsurface drip irrigation method. Journal of Irrigation and Drainage Engineering. Vol. 745. Iss. 1 p. 733-743.

Netzer Y., YaO C.R., Shenker M., Bravdo B.A., SCHWARTZ A. 2009. Water use and the development of seasonal crop coefficients for Superior Seedless grapevines trained to an open-gable trellis system. Irrigation Science. Vol. 27. Iss. 2 p. 109-120.

Rodriguez-Sinobas L., Gil M., Juana L., Sanchez R. 2009. Water distribution in laterals and units of subsurface drip irrigation. I: Simulation. Journal of Irrigation and Drainage Engineering. Vol. 135. Iss. 6 p. 721-728. DOI: $10.1061 /(A S C E) I R .1943-4774.0000058$.

Rossi G., CANCElliere A. 2002. At-site and regional drought identification by Redim model. In: Tools for drought mitigation in Mediterranean regions. Eds. G. Rossi, A. Cancelliere, L.S. Pereira, T. Oweis, M. Shatanawi, A. Zairi. Ser. Water Science and Technology Library. Vol. 44. New York. Springer p. 37-54.

SAXENA M. (ed.) 2015. Indian Horticulture database. New Delhi. Ministry of Agriculture, Government of India pp. 286.

SIKKA D.R. 2009. Two decades of medium-range weather forecasting in India: National Centre for Medium-Range Weather Forecasting. Center for Ocean-Land-Atmosphere Studies Technical Report. No. 276 pp. 100.

Steduto P., Hsiao T.C., Fereres E., Raes D. 2012. Crop yield response to water. Irrigation and Drainage Paper. No. 66. Rome. FAO p. 270-275. 


\section{Sharad J. KADBHANE, Vivek L. MANEKAR}

Badania powierzchniowego i podpowierzchniowego nawadniania w nawiązaniu do wilgotności gleby w winnicy

\section{STRESZCZENIE}

Przeprowadzono eksperyment polowy w winnicy w czasie lata, pory mokrej i zimowej, stosując różne metody nawadniania i mierząc jego wpływ na zachowanie wilgotności w glebie. Zastosowano sześć metod nawadniania: nawadnianie kroplowe, nawadnianie kroplowe z przykrywaniem syntetyczną włókniną, nawadnianie kroplowe $\mathrm{z}$ mulczowaniem organicznym, podpowierzchniowe nawadnianie z kolumnami z kamieni, podpowierzchniowe nawadnianie $\mathrm{z}$ glinianymi naczyniami i nawadnianie za pomoca butelek plastikowych. Do oceny zapotrzebowania uprawy na wodę zastosowano model CROPWAT 8.0. Wilgotność gleby mierzono czujnikami wprowadzonymi do gleby na głębokość 30 i $60 \mathrm{~cm}$. Parametry klimatyczne uzyskano z automatycznej stacji pogodowej usytuowanej w pobliżu pola doświadczalnego. Wieloczynnikową analizę statystyczną przeprowadzono z wykorzystaniem pomierzonej wilgotności gleby i danych klimatycznych. Metoda kroplowego nawadniania z przykrywaniem syntetyczną włókniną okazała się najlepsza spośród wszystkich zastosowanych metod z powodu największej retencji wilgoci glebowej (25-30\%). Użyteczna okazała się także metoda podpowierzchniowego nawadniania z plastikowymi butelkami, ponieważ zatrzymywała $15-20 \%$ wilgoci glebowej.

Slowa kluczowe: ceramika porowata, mulczowanie, nawadnianie kroplowe, nawadnianie podpowierzchniowe, nawadnianie powierzchniowe, retencja wody glebowej, włóknina syntetyczna 